\title{
Szuburbanizáció a határon át: társadalmi, etnikai és arculati változások Rajkán
}

\author{
Rajka: The "Hungarian suburb" of Bratislava
}

\author{
BALIZS DÁNIEL, BAJMÓCY PÉTER
}

BALIZS Dániel: tudományos munkatárs, Budapesti Műszaki és Gazdaságtudományi Egyetem, Urbanisztika Tanszék; 1111 Budapest, Műegyetem rkp. 3.; balizs.daniel@urb.bme.hu; https://orcid.org/0000-0003-4700-4183

BAJMÓCY Péter: egyetemi docens, Szegedi Tudományegyetem, Gazdaság- és Társadalomföldrajz Tanszék; 6722 Szeged, Egyetem utca 2.; bajmocypeter@hotmail.com; https://orcid.org/0000-0003-1692-4825

KULCSSZAVAK: szuburbanizáció; etnikai mintázat; társadalmi átalakulás; építészeti arculat; Rajka

ABSZTRAKT: A Magyarország északnyugati peremén található Rajka földrajzi helyzete speciális, mivel alig húsz kilométerre található a szlovák fővárostól, Pozsonytól. A település mintapéldája a határon átívelő szuburbanizációnak, melynek folyamán az urbánus népesség célterülete nem csupán a nem túl távoli vidéki térség, hanem - ingatlanpiaci, elérhetőségi stb. okokból - annak a szomszédos országban fekvő része. Rajkán az egy évtizede tartó folyamat révén napjainkban 2000 „őshonos” és 3000 bevándorló él. Utóbbiak magyar állampolgárságot nem igényelnek, és döntő részben a község társadalmi életéből sem veszik ki részüket. A két közösség között - életmódbeli különbségeik következtében - alig van kapcsolat, annak ellenére, hogy a betelepülők egy része magyar anyanyelvü. Új lakónegyedek és felújított ingatlanok révén Rajka építészeti arculata fokozatosan átformálódik. A régi lakóházak felújítása és átalakítása a község régi településrészén jellemző, ahol gyorsan nő a pozsonyi hátterűek lélekszáma. Míg az új építésű utcákban csaknem kizárólag betelepülők élnek, Rajka régebbi utcáiban élő népesség vegyes. A tanulmány bemutatja a társadalmi változásokat, az új lakosok etnikai és származási hátterét, valamint a településarculat átformálódásának leginkább szembetűnő elemeit.

Dániel BALIZS: research fellow, Department for Urban Planning and Design, Budapest University of Technology and Economics; Müegyetem rkp. 3., H-1111 Budapest, Hungary; balizs.daniel@urb.bme.hu; https://orcid.org/0000-0003-4700-4183

Péter BAJMÓCY: associate professor, Department of Economic and Social Geography, University of Szeged; Egyetem utca 2., H-6722 Szeged, Hungary; bajmocypeter@hotmail.com; https:// orcid.org/0000-0003-1692-4825

KEYWORDS: suburbanisation; ethnicity; built environment; Hungary; Slovakia; Rajka

ABSTRACT: Rajka is a village in Northwest Hungary with a special geographical location: it is situated only twenty kilometres from Bratislava, the capital of Slovakia. In the past decade,

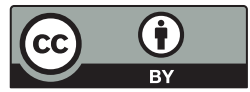


Rajka's population and appearance went through significant changes. The village became practically a suburb of Bratislava within a few short years. Its population doubled, and $60 \%$ of its residents are of Slovakian nationality now. This settlement, located 180 kilometres from Budapest, is an excellent example of the phenomenon of cross-border suburbanisation, an urban population migrating from a city to a surrounding rural area - even if it is in another country.

Rajka has 2,000 indigenous and as many as 3,000 immigrant inhabitants. The majority of the immigrants are Slovakian citizens who do not participate much in community life. The two populations have entirely different lifestyles, and there is an interactional gap between the "old Rajka" natives and the newcomers although for some Hungarian is their mother tongue.

The new inhabitants live in a total of 500 properties. Two-thirds of them found homes in new residential estates east of the village and many moved into the old streets as part of a mosaic-like pattern of coexistence. The changes in Rajka meant the disappearing of a rural milieu. The better financial background of the new residents is an important reason: Often they would buy the natives out of their properties, frequently bidding much higher than market prices. As a consequence, real-estate prices in Rajka rose quickly, doubling within a few years.

The newcomers are also changing the architectural character of the village by building new structures. Or they move into remodelled houses in the old part of Rajka. Many streets are now inhabited by mixed populations. Residents (old and new) who would like to preserve the rural touch of Rajka face a difficult decision: If building zones are not expanded the locals will move away and be replaced by newcomers from Bratislava. However, assigning new building plots will accelerate population growth.

Besides investigating social changes, this paper focuses on the ethnic ancestry and geographical origins of the immigrants, often manifested in new linguistic and social patterns. Researching the specifics of significant changes in the architectural character of Rajka is another important element of the study.

\section{Bevezetés}

A Magyarország, illetve Győr-Moson-Sopron megye északnyugati peremén elhelyezkedő Rajka a második világháborút lezáró párizsi békétől (1947) - amikor a község a (cseh)szlovák igények ellenére Magyarország része maradt - a közelmúltig északi szomszédunk felé határátkelőként funkcionált. Az eredetileg német többségű falu történelmében nagy törést jelentett a német ajkúak tömeges kitelepítése, helyükre főként Csehszlovákiából telepítettek magyarokat. A határ menti falut a szocializmus idején alig fejlesztették. Ebből adódóan jellemző társadalmi folyamata az elvándorlás volt, főként Mosonmagyaróvár és Győr felé.

Új helyzetet Magyarország és Szlovákia európai uniós csatlakozása (2004), majd a két ország közötti határellenőrzés megszűnése (2007) hozott. Rajka a szlovák fővárostól, Pozsonytól alig 20 km-re található, így a 20. század eleji határmódosulások révén megszünt térkapcsolatok felélénkülése - más határ menti térségekhez (pl. Nagyvárad, Arad, de akár Szombathely) hasonlóan - a nagyvárosi vonzáskörzetek újjászerveződésének lehetőségét hozta magával. Rajka Pozsony potenciális szuburbiájává „lépett elő”, és a már részben telített városkörnyéki településekkel szemben versenyelőnybe került: a kevésbé zsúfolt Rajkán az ingatlanárak alacsonyabbak voltak, mint a szlovák részen. 
A pozsonyi betelepülők Rajkára történő tömeges beáramlása az utóbbi időben a hazai sajtóban is publicitást kapott. A község arculatában bekövetkező változások, a társadalmi átalakulás, a közösségek együttélése, illetve a lehetséges következmények mind-mind aktuális kérdésekként jelennek meg, melyek a közeljövőben más magyarországi községekben (főként a román határ menti vidékeken) is relevánssá válhatnak. A megjelent tanulmányok alig foglalkoztak a társadalmi folyamatok térbeli leképeződésével, a formálódó nyelvi-társadalmi viszonyok utca-, netán háztartási szintű bemutatásával, vagy éppen az arculatváltás idő- és térbeli kontextusba illesztésével. E tanulmány célkitűzései a következők:

- Első célként a hazai és külföldi (szlovák) írott médiafelületeken megjelent riportok feldolgozását, Rajka demográfiai, arculati, nyelvi, ingatlanpiaci stb. átalakulásának összegzését határoztuk meg, kiegészítve a kevés számú tudományos publikációból, valamint saját adatközlőinktől nyert információkkal.

- Fontosnak tartottuk a helyi nyelvi-etnikai viszonyok felmérését, az új rajkai lakosok nyelvi, nyelvtudásbeli, állampolgársági stb. jellemzőinek elemzését. Feltételezésünk az volt, hogy az etnikai términtázat átalakulása - bár a mindennapok szintjén nem vezet rendszeres konfliktusokhoz - érzékelhető hatást gyakorol nemcsak a helyi közösségre, hanem Rajka vizuálisan felmérhető részeire (pl. köztereire) is.

- Rajka átalakulása rendkívül gyorsan zajló folyamat, ezért célul tűztük ki a települési arculat jelenlegi és korábbi állapotának összevetését.

\section{Módszertan}

Rajka jelenlegi helyzetének bemutatásához a hazai publicisztikában korábban megjelent beszámolók megfelelő hátteret szolgáltattak, e cikkekre, helyszíni bejárásokra szakirodalmi háttérként tekintünk, melyet kiegészítenek helyi adatközlőink információi. Helyismeretüknek köszönhetően nemcsak a település témánk szempontjából releváns részeit fedezhettük fel, hanem véleményükből, személyes történeteikből (a helyi ingatlanpiac helyzete, a migráció jellemzői, a lokális konfliktusok stb. kapcsán) az utóbbi évtizedben lezajlott, földcsuszamlásszerű változásokkal kapcsolatos álláspontjuk is kibontakozik.

Míg a kérdéskör hazai szakirodalmát bővítésre érdemesnek gondoljuk (e cikk is részben ennek jegyében készült), addig a magyar és a szlovák média viszonylag hamar felkapta a beköltözések témáját. A regionális illetőségü Kisalföld mellett országos sajtóorgánumok (Magyar Nemzet, Heti Világgazdaság) és szlovák napilapok, folyóiratok foglalkoztak a község sajátos fejlődésével. Az ezekben megjelent anyagok közül mintegy 20 cikk feldolgozását végeztük el. 
A települési arculat vizsgálata során a változásokra helyeztük a hangsúlyt, ami Rajka esetében már néhány éves viszonylatban is jól mérhető. A helyszíni szemle (2017. április) során mintegy 250 fotó készült, amelyeket a Google Street View 2011. decemberi adatbázisával vetettük össze. Az alig hatéves időszakban Rajkán markáns átalakulás ment végbe.

A nyelvi és etnikai mintázat felméréséhez kipróbált módszerek álltak rendelkezésünkre: a helyi viszonyokat alaposan ismerő informátorok bevonása, a háztartási szintű felmérés a települések belső etnikai struktúrájának vizsgálatakor (bővebben lásd Balizs 2014; Keményfi 2002; Tátrai 2006); a térképezés és a fotódokumentáció. A fellelhető helyszíni információk minél nagyobb hányadának összegyüjtése volt a cél.

Az „őshonos” és „„slakos” szóval Rajka esetében óvatosan kell bánnunk, hiszen a jelenleg Rajkán élö, magyar állampolgárságú népesség számottevő hányada is csupán a második világháború végéig tudja visszavezetni családjának rajkai származását. A magyarokat és a kisszámú helyben maradt német lakosságot nevezzük őshonosnak, annak érdekében, hogy megkülönböztessük az ezredforduló után Pozsonyból áttelepülőktől.

A lakosság származási hátterének megállapításához használható információnak minősültek az utcákon haladó vagy parkoló járművek rendszámai, illetve a különböző (szlovák vagy magyar) rendszámú autók előfordulásának sajátosságai. (A rendszámtáblák információtartalmára több tanulmány is felhívja a figyelmet - Du et al. 2012; Prates et al. 2014 -, melyekben a tulajdonos részleges azonosítása szerepel célként. László és szerzőtársai (2011) a turizmuskutatásban a vendégek származási országának azonosításához használták a rendszámtáblákat.)

Figyelemmel Rajka sajátos belső struktúrájára, fragmentálódó településszövetére, különbséget tettünk a község több évszázadra visszavezethető, de jelenlegi épületállományát tekintve fóként 1960 és 1980 között épült régi, valamint a szinte csak pozsonyi származásúak által benépesített, 2007 óta épülő új településrészei között. A változások térbeli leképeződését térképen ábrázoltuk, mely áttekintést nyújt a társadalmi-migrációs folyamatokról és a jelenlegi nyelvi struktúráról. Így végső soron a tanulmányban alkalmazott módszertan a szakirodalmi feldolgozás - adatközlók megkérdezése - helyszínbejárás - fotózás - vizualizáció logikai menete.

\section{Az országhatárzónák megélénkülése}

Nyugat-Európában a schengeni egyezmény 1985-ös megkötését követően váltak szabadon átjárhatóvá az országhatárok (a német-holland, a belga-holland és a francia-német határ relációjában lásd Strüver 2005; Terlouw 2008; Van Houtum, Gielis 2006), de meg kell jegyezni, hogy már 1985 előtt is lazább volt a ha- 
tárellenőrzés a korábbiakhoz képest. A schengeni szerződés drámai változást hozott az EU-hoz csatlakozott közép-európai térségben, és megnyitotta a fejlödés lehetőségét a többnyire elmaradott országhatárzónákban is.

A határ túloldala iránti érdeklődés eleinte általában a munkahelyi mobilitás (ingázás) növekedését hozta magával, majd az eltérő ingatlanárak révén fokozódott a lakóhelyi mobilitás is, ideiglenes áttelepülés vagy végleges átköltözés formájában. A határt átlépő lakossági mozgásban nagy szerepe van az etnikai, származási, nyelvi tényezőknek - bár Rajka esetében kisebb mértékben.

Számos esetben, ha az országhatár zónája urbanizáltságban és/vagy gazdasági potenciálban aszimmetrikus jellegü, a mobilitás határt átlépő szuburbanizáció formájában jelenik meg (a szuburbanizáció számtalan aspektusból vizsgált folyamatának elméleti hátteréhez lásd Bajmócy 2007; van den Berg et al. 1982; Dövényi, Kovács 1999; Enyedi 1988; Fishman 1987; Timár 1999). Egyszerủbben fogalmazva, az országhatár közelében fekvő nagyvárosból a kiköltözők különböző - ingatlanpiaci, elérhetőségi, esztétikai stb. - okokból a szomszédos ország közeli települését választják. Sajátos eset, amikor az elköltöző városának természetes vonzáskörzetébe tartozik a határ túloldalán lévő település. Az országhatár - annak merevsége folytán - e folyamatnak gátat szab, ha viszont átjárhatóvá válik, az addig lefojtott kereslet azonnal jelentkezik (Hardi 2010; Jagodič 2010).

Magyar viszonylatban a 20. század elején határainkon túlra került, majd az 1989 utáni politikai változások után dinamikus fejlődésnek induló városokat említhetjük, melyek természetes vonzáskörzete - a korábban oda gravitáló települések és népesség kisebb-nagyobb hányada - Magyarországon maradt. E területek a múlt században periferikus helyzetbe kerültek, centrumuk elvesztését más városok legfeljebb csak részben pótolták. Példaként elsősorban Nagyvárad (Lovas Kiss 2011) és Kassa hozható fel (Jagodič 2011). Pozsony is e városok közé tartozik, azzal a különbséggel, hogy esetében a vonzáskörzet döntő hányada is a határ túloldalára került, csupán néhány település (közöttük Rajka) maradt Magyarország része. Pozsony egyedi jellegét adja továbbá, hogy fővárosról van szó, s ez a tény mind a népességszám (tehát a szuburbán folyamatokban potenciálisan részt vevő népesség), mind a lakosság egyéb társadalmi jellemzői (jövedelmi viszonyok, képzettségi szint, mobilitás stb.) kapcsán a szuburbanizációnak különösen nagy lendületet biztosít.

A szlovák fővárost a rendszerváltás negatív hatásai kismértékben érintették; gazdaságának, térségi szervező erejének Szlovákia önállóvá válása - 1993 után - még inkább lendületet adott. Lakosságszáma a 20. század második felében gyorsan nőtt: négy rövid évtized alatt 193 ezerről 442 ezer före. A növekmény számottevő hányada az új ipari üzemek működését biztosító munkaerő beáramlásából adódott. A migrációs háttér a - generációs késleltetéssel történő - továbbköltözéshez szükséges rugalmas politikai-adminisztratív hozzáállásban mutatkozik meg, s ez Pozsony esetében a szuburbán folyamat fontos bázisát jelenti. (A 2010 előtt Rajkára költöző pozsonyiak legalább egyharmada 
nem a szlovák fővárosban született - Lampl 2010.) A város agglomerációjának terjeszkedése évtizedekkel ezelőtt kezdődött el, először a fő közlekedési folyosók mentén (Brno, illetve Nagyszombat felé), majd a Csallóköz felé és a határ túloldalán. A szlovák-magyar határ nyugati szakaszának intenzív és kölcsönös kapcsolatrendszere már a szocializmus idején kiépült, főként munkaerőcsere formájában (Hardi 2011). Az ezredforduló környékén a szlovákiaiak nagyobb arányban látogatták Magyarországot (a megkérdezettek 94\%-a), mint fordítva (80\%), aminek feltehetően nyelvi okai is voltak (Hardi 2008). Ebben az időszakban a Pozsony környéki szlovák-magyar határszakaszon élő szlovákiaiak 50\%a értékelte előnyként a szomszédos országhoz való közelséget, a határ magyar oldalán mindössze ennek tizede (Hardi, Lampl 2008). Hardi 2009-es kutatásában különös figyelmet fordított a nyelvi attitüdre; megállapította, hogy az addig Rajkára költözők 80\%-a szlovák nemzetiségű volt, viszont minden második személy beszélt/értett valamilyen szinten magyarul. A szerző újabb kutatása szerint a pozsonyi agglomeráció szlovák oldalán élő szlovákiai magyarok mindössze 29\%-a szerint lehet megélni szlovák nyelvtudás nélkül, míg a magyar oldalon a kiköltözők 76\%-a úgy vélekedett, hogy magyar nyelvtudás nélkül is boldogulhat. Ez szoros összefüggésben áll azzal, hogy a Magyarországra költözők egy részének nem áll szándékában beilleszkedni az új társadalmi közegbe, mivel nincs is rá szüksége; az, hogy többségük otthon érzi magát Rajkán, nem jelent identitásváltást (Hardi 2011). Négyötödük véleménye szerint a helyiek segítőkészen és barátságosan fogadták őket, függetlenül attól, hogy szlovák vagy magyar nemzetiségü volt az illető (a hazaiak a Magyarországra települőket nemzetiségre való tekintet nélkül külföldiként kezelik - Hardi, Lampl 2008). Az elköltözésnek nem volt számottevő hatása munkahelyi mobilitásukra, 82\%-uk Pozsonyban dolgozott, s csak mindössze egytizedük jelenlegi lakhelyén, Rajkán (Lampl 2010).

\section{„Itt már Pozsony dirigál"1}

Rajka társadalmának, nyelvi és arculati képének átalakulása a helyiek elmondása szerint a 2004-es európai uniós csatlakozást követően azonnal elindult. A folyamat hirtelen felfutásának okai illeszkednek a nemzetközi példákhoz:

- határközeli nagyváros, a határ túloldalán rurális térség;

- határnyitás, a költözés fizikai korlátainak lebontása;

- a vidéki életmód, a csendes és természetközeli lakókörnyezet iránti igény;

- kiváló közlekedési kapcsolat a nagyváros és a szuburbán zóna között;

- hasonló kulturális és társadalmi közeg a határ két oldalán, ami megkönnyíti a beilleszkedést;

- a mindennapi fogyasztási cikkek csaknem megegyező árszínvonala; 
- az ingatlanárakban számottevő differencia mutatkozik, ami a városban élőket lakásuk vagy házuk értékesítésére és új (rajkai) lakóingatlan vételére ösztönzi.

2008-ig Rajkán 130-140 ingatlan került „szlovák” (pozsonyi) tulajdonba, az átköltözők száma elérte a 400 főt. Az első tapasztalatokat követően nyilvánvalóvá vált, hogy

- az érkezők jövedelmi helyzete sokkalta kedvezőbb a rajkaiakénál, ami hamar a határ innenső oldalán lévő, eredetileg épp olcsóságuk miatt vonzó ingatlanok felértékelődéséhez vezet;

- a helyi épületek, telkek árának emelkedése a rajkaiak elvándorlását eredményezi, mivel a családalapítás előtt állók képtelenek kifizetni ekkora összegeket (hiába támogatja őket a helyi önkormányzat), az ingatlannal rendelkezőknek pedig egyre inkább megéri eladni a tulajdonát, majd elköltözni;

- az újonnan érkezetteknek a helyi társadalmi (közösségi élet, oktatási, egészségügyi és szociális intézmények látogatása, lokális interakciók, önszerveződés) és gazdasági (a helyi kereskedelmi egységek használata, hozzájárulás a település bevételeihez) közegbe történő beágyazottsága minimális - bár az elmúlt években lassú javulás tapasztalható;

- a pozsonyiak beáramlása nem korlátozódott Rajkára, hanem a környező településeken (Bezenye, Dunakiliti, Feketeerdő, Mosonmagyaróvár stb.), sőt az osztrák oldalon (Deutsch Jahrendorf - Németjárfalu, Kittsee - Köpcsény) is jelentkezett.

Az ingatlanárak emelkedése az elmúlt években Pozsony szűkebb és tágabb környékén egyaránt általános jelenség. Rajka esetében - a korábbi relatív olcsóság és a kereslet hirtelen felfutása miatt - ez a növekedés dinamikusabb a szlovákiai oldalon tapasztaltnál. Hazai ingatlanportálokról és szlovák statisztikákból gyüjtött adatok szerint 2008-ban a pozsonyi ház-, lakás- és telekárak három-ötszörösen múlták felül a rajkai átlagot. Alig 9 évvel később a különbség már csak másfél-kétszeres. Időközben a rajkai ingatlanárak megközelítették a Pozsony környéki, szuburbanizáció által jóval erősebben érintett falvak átlagát, holott korábban ott is tetemes volt a különbség (1. táblázat). Rajkán egy ház vagy lakás több mint kétszer annyiba kerül, mint 2008-ban, a telkek esetében ennél kisebb volt az áremelkedés.

1. táblázat: Az ingatlanárak alakulása Pozsonyban és környékén, illetve Rajkán 2008-2017 között (Rajka=100)

Property prices in Bratislava, Bratislava region and Rajka between 2008 and 2017 (Rajka=100)

\begin{tabular}{lcccccc}
\hline Terület & \multicolumn{3}{c}{2008} & & \multicolumn{3}{c}{} \\
\cline { 2 - 7 } & ház & lakás & telek & ház & lakás & telek \\
\hline Pozsony & 320 & 470 & 450 & 147 & 222 & 228 \\
Pozsony környék & 220 & 220 & 375 & 123 & 156 & 158 \\
Rajka & 100 & 100 & 100 & 100 & 100 & 100 \\
\hline
\end{tabular}

Adatok forrása: ingatlan.com, ingatlannet.hu, nehnutelnosti.sk 
A lokális tér eddig nem tapasztalt átformálódása mindkét - az őshonos és a betelepülő - közösség számára új kihívásokat jelent. Az őshonos rajkaiak ugyan - az osztrák németjárfalusiakkal ellentétben - nem helyeztek el jelképes stoptáblát a falu felé vezető (föld)útra, ám felemásnak értékelik az új helyzetet:

- A beköltözők létszáma, képzettsége, jövedelmi helyzete imponáló, ami a tősgyökeres népesség szerint nagyban hozzájárul a község életének „felpezsdüléséhez".

- A község vezetése és lakossága egyaránt nehezményezi, hogy a beköltözők használják a település infrastruktúráját, azonban döntő hányaduk változatlanul Pozsonyban dolgozik és adózik, illetve jelentős részük bejelentés nélkül él Rajkán. Ez a hazai állami - normatív és feladatalapú - támogatási rendszer okán ellentmondásos helyzetet teremt (Tarics 2008).

- Az őslakos rajkaiak nem nézik jó szemmel a község megítélésük szerint túl gyors arculatváltását, az urbánus életforma terjedését, a megnövekedett forgalmat és - a szlovák anyanyelvűek esetében - a gyenge magyartudást.

- Gyakori panasz, hogy az ingatlanárak hirtelen emelkedése nagy nyomást gyakorol az őslakos családokra, akik számos esetben hitelből vásároltak saját házat. Így a beköltözők azáltal, hogy a hazai piaci áraknál jóval többet is hajlandók kifizetni, lényegében ingatlanjuk eladására és a faluból történő elköltözésre bírják rá a helyieket.

2008-ig Rajka lakosságának 10\%-a cserélődött ki, 2009-ben a lakosok ötöde már „szlovák”. Eddig az óvodából 13 „őslakos” gyermeket vettek ki a szüleik elköltözés miatt (Élő 2008), ugyanakkor 2009 után az intézmény egyre népszerübb lett a beköltözők körében, ami szükségessé tette szlovákul beszélő óvónő alkalmazását (Munk 2009). 2015-ben a beíratott 69 gyermek harmada (Bartalos 2015), 2017-ben már 35-40\%-a pozsonyi hátterű. Sajátos módon a helyi iskola nem mutat hasonló trendet (csaknem mindenki pozsonyi tanintézetet választott), 2015-ben a 149 tanulóból mindössze egy szlovák állampolgár (Teraz.sk 2015). Az elköltözések hatása itt is érződik, a tanulók száma 2006 és 2009 között 13\%-kal csökkent. A német kisebbségi múlt viszont éppen az általános iskola kapcsán érhető tetten, a nemzetiségi nyelvet oktató intézményben a német nyelvet már első osztálytól emelt óraszámban tanítják, a fenntartási költségekből a helyi német nemzetiségi önkormányzat is kiveszi a részét. A kétnyelvű, kettős identitású német kisebbség a hagyományápolás terén is aktív, és az adatközlők szerint alapvetően jól alkalmazkodik a megváltozott helyzethez (mivel más nemzetiségi csoport is megjelent a faluban). A beköltözők szlovák önkormányzatot addig nem alapíthatnak, amíg nem veszik fel a magyar állampolgárságot, ez viszont a kettős állampolgárságot nem engedélyező szlovák törvény miatt nem várható.

A pozsonyi hátterü rajkaiak új lakóhelyükkel nagyon elégedettek (Lampl 2010). ${ }^{2}$ A fővárosból kiköltözők körében a magyarországi települések pozitívabb értékelést kaptak, mint a Pozsony környéki csallóközi községek. A különbség 
főként az autóval történő megközelíthetőség miatt számottevő: Rajkáról és a környező hazai falvakból (az M15-ös autópályán) Pozsony mindössze 15 perc alatt elérhető, gyorsabban, mint a környező szlovákiai településekről. A másik tényező, melyben Rajka megítélése bizonyult jobbnak, a helyi közösségbe történő beilleszkedés és a nyelvi szempont. Ez némi magyarázatra szorul, hiszen Pozsonyból akár a Csallóköz, akár Magyarország irányába indulunk, magyar nyelvű közegbe érkezünk. Az eltérő megítélés okai inkább az elvárásokban keresendők: a kiköltöző, többségében szlovák nyelvű családok a szlovák oldalon fekvő csallóközi magyar falvakban elvárták, hogy új lakóhelyükön is maradéktalanul meg tudják értetni magukat az anyanyelvükön, míg Rajkán és környékén már az is gesztusértékü, ha akár csak néhány személlyel tudnak szlovákul kommunikálni (Lampl 2010). Természetesen körükből is érkeznek panaszok, melyek szintén az életmódbeli különbségekre vezethetők vissza (nem befogadó a helyi közösség, hiányos vidéki infrastruktúra stb.): „Ez az otthonom, de egyúttal vendég is vagyok itt. Ezt észben kell tartanunk és ennek megfelelően viselkednünk. Európai polgárok vagyunk, közösek az érdekeink. Fontos, hogy elkerüljük a negatív sztereotípiákat, és az, hogy ne csak a saját érdekeinket vegyük figyelembe." (idézi Krupčíková 2013). Előbbi idézet egy Pozsonyból kiköltöző szlovák férfitől származik, akinek felesége szlovákiai magyar, gyermekei pedig kétnyelvűek. A „kiköltözési láz” elején érkeztek Rajkára, munkájuk, kapcsolataik javarészt Pozsonyhoz kötik őket, ugyanakkor jó a viszonyuk a helyiekkel, és a legtöbb más kiköltöző családtól eltérően gyermekeiket a rajkai iskolába járatják. A fenti néhány mondat jól jellemzi az új lakosok óvatos attitűdjét, kiolvasható belőle a beilleszkedésre törekvés, de az is, hogy ehhez az őslakosok megfelelő hozzáállása is elengedhetetlen. A közösségi integrációra viszont nem mindenki vágyik: előfordul olyan is, hogy az új lakosok azért érzik jól magukat, mert a Rajka szélén felépült új lakónegyedben „összetartó szlovák közösség él” (Nový Čas 2015). E vélemény más megfogalmazásban, más tartalmat sugallva is felismerhető: „Nekünk jó, hogy ide jönnek, mert épül-szépül a falu. Előfordul néha, hogy az emberek szidják egymást, de ez más falukban is megtörténik. Az úgynevezett szlovák negyedben összetartóbbak az emberek, mint a régi rajkaiak" (idézi Bartalos 2015).

Konfliktus, jelentősebb tiltakozás csak az első években fordult elő, közterületi feliratok, graffitik („Tótok, a magyar föld nem eladó!”) (Borsodi 2008), a szlovák rendszámú járművek rongálása, az országhatárra szervezett tüntetés (melyen a helyiek szerint egy rajkai lakos sem vett részt) formájában. A hangulatkeltés szlovák oldalról is megjelent, az egyik ingatlanközvetítő részéről, aki az immigránsok helyzetéről lehangoló képet festett, állítása szerint „a szlovákok 70\%-a az incidensek miatt csomagolni akar, másik részük vívódik, hogy maradjon-e". A kijelentést a rajkai szlovákok felháborodással fogadták, hangsúlyozva a helyiekkel való békés együttélést (Cséfalvay 2008). Az adatközlők és a helyszíni riportok egybehangzó tapasztalatai alapján a régi és az új lakosok közötti ellentét korán elvesztette etnikai dimenzióját, manapság - alacsony intenzitással - inkább 
szemlélet- és életmódbeli eltérések táplálják (városi vagy vidéki életmód, őslakos vagy „gyüttment”) (Mészely 2010). A hétköznapi érintkezés során kevés súrlódás akad, a két közösség közeledésére nyílik lehetőség a mindenki számára nyitott programok, klubok, alkalmak (baba-mama klub, sportegyesületek stb.) keretében. Adatközlőink szerint az új lakók a rajkai községi rendezvényeket csak elvétve látogatják, ez a lokális identitás kiforratlanságát jelzi. A közös idő eltöltésére megfelelőbb helyszínnek bizonyulnak a vendéglátóhelyek, ezek között érdemes megemlítenünk a pár éve a falu déli részén megnyílt „szlovák kocsmát", melyet egy áttelepült szlovákiai magyar vállalkozó működtet. A kocsmát magyarok, szlovákok egyaránt látogatják (Krupčíková 2013).

Ahogy korábban említettük, Rajka nem a migráció egyedüli célpontja. Győr-Moson-Sopron megyében 2001 és 2011 között a magukat szlováknak vallók száma kilenszeresére nőtt (195-ről 1802 főre). 2011-ben Rajkán éltek a legtöbben (535 fö, a község lakosságának 19\%-a; emellett 284 fös német, jobbára kétnyelvű közösség is él a településen), számottevő szlovák közösségnek adott otthont Mosonmagyaróvár (284 fó, 0,9\%), valamint Bezenye (131fo,, 9\%) és Dunakiliti (126 fö, 6\%). A mosonmagyaróvári járásban 10 és 100 fő közötti szlovákság lakta Dunasziget, Feketeerdő, Hegyeshalom, Levél, Máriakálnok, Mosonszolnok és Ujrónafo" községeket is; ami azt jelenti, hogy 2011-ben a járás szlovákságának csupán 40\%-a élt Rajkán (KSH é. n.). Adatközlőink szerint 2017-ben Feketeerdőn elérte a $20 \%$-ot, Bezenyén és Dunakilitin a 10\%-ot a beköltözők aránya, Rajka után a második legnagyobb „szlovák” közösség (500-600fö) Mosonmagyaróváron élt (Herczeg 2012). ${ }^{3}$

Sajátos példával szolgált a Rajkától pár kilométerre délre fekvő Bezenye. A község viszonylag zárt, hagyománytisztelö, horvát identitású népessége a kezdetektől ellenszenvvel fogadta a rajkainál egyébként jóval kisebb számú betelepülőt. Bezenye összefogott „a falu szokásait fel nem vevő”, „minden írott és íratlan szabályt felrúgni akaró" betelepülők ellen, ami az új lakók ingatlanjait és járműveit célzó támadásokban nyilvánult meg, annak ellenére, hogy az esetek egy addig alapvetően törvénytisztelő faluban történtek. Az őslakosság ráadásul nemcsak a pozsonyiaktól, hanem a házukat eladni akaró helyiektől is elhatárolódott, utóbbiakra a „hazaáruló” bélyeget sütve. A bezenyeiek (és ez a rajkaiakra is igaz) az újonnan érkezőktől a helyi viszonyokhoz történő alkalmazkodást várják, és ennek vélt vagy valós elmaradása konfliktusokat generál (Borsodi 2008; Cséfalvay 2010). Mindezek ellenére a régi és új közösségek együttélése alapvetően békés, az első pár év okozta sokk óta egyértelmű javulás tapasztalható. A korai konfliktusokat az emberek inkább a „nagypolitika” számlájára írták, így a helyi ellentétek csökkenése és a magyar-szlovák államközi kapcsolatok utóbbi években megfigyelhető normalizálódása között is lehet összefüggés.

2009-ben 500, 2010-ben 900, 2012-ben pedig már 1400 volt az átköltözők száma, ami azt mutatja, hogy az időközben kibontakozó gazdasági válság sem apasztotta a pozsonyiak migrációs lendületét (2. táblázat). A folyamatos kereslet hatására az ingatlanárak növekedése folytatódott. Már nemcsak családi há- 
2. táblázat: Az ingatlanok és a lakosság számának változása Rajkán Changes in the number of housing units and inhabitants in Rajka

\begin{tabular}{|c|c|c|c|c|c|c|c|}
\hline \multirow[t]{3}{*}{$E ́ v$} & \multirow{3}{*}{$\begin{array}{c}\text { Lakóingatlanok } \\
\text { száma }\end{array}$} & \multicolumn{2}{|c|}{ Lakosságszám } & \multicolumn{3}{|c|}{ Arányok (\%) } & \multirow{3}{*}{$\begin{array}{c}A \\
\text { bejelentkezettek } \\
\text { aránya }(\%)\end{array}$} \\
\hline & & \multirow[t]{2}{*}{ KSH } & \multirow[t]{2}{*}{ Becsült } & \multirow[t]{2}{*}{ "Öshonos" } & \multicolumn{2}{|c|}{ "Beköltözo"” } & \\
\hline & & & & & Szlovák & Magyar & \\
\hline 2007 & 930 & 2504 & 2500 & 100 & 0 & & 100 \\
\hline 2009 & 949 & 2385 & 2800 & 80 & 16 & 4 & 85 \\
\hline 2012 & 1161 & 2561 & 3600 & 61 & 29 & 10 & 71 \\
\hline 2015 & 1339 & 2607 & 4500 & 49 & 36 & 15 & 58 \\
\hline 2017 & 1556 & 2843 & 5300 & 43 & 38 & 19 & 54 \\
\hline
\end{tabular}

Forrás: Bartalos 2015; Borsodi 2008; Hvg.hu 2012, 2017; KSH 2017; Munk 2009; Torontáli 2017.

zakat építettek vagy vásároltak, 2012-ben négy, egyenként 29 lakásos társasház építése volt folyamatban (Hvg.hu 2012), ezek időközben elkészültek. 2013-ban 131 új építési telket parcellázott az önkormányzat (Cseke 2013). A kitelepülők volt lakóhelyéről csak közvetett információink vannak, valószínűsíthetően eleinte főként Pozsony földrajzilag legközelebb fekvő, mintegy 106 ezer főnek otthont adó városrészéből, a szinte tisztán lakótelepekből álló Petržalkából érkeztek. A későbbiekben adatközlőink már „kevert” helyzetről számoltak be, földrajzi (a pozsonyi bel- és külváros, lakótelepek), illetve migrációs (pozsonyi „őslakosok” és néhány éve odatelepültek) háttér szempontjából egyaránt.

2015-ben Rajka lakosságszáma meghaladta a 4500 föt, már több mint 50\%-uk pozsonyi származású (Bartalos 2015). A frissen parcellázott, alig pár év alatt telítődő új lakónegyedekben lényegében mindenki szlovákiai hátterü, arányuk a falu régi belterületén is ugrásszerüen nőtt, adatközlőink szerint 2017-re itt is többségbe kerültek: „A látogatónak első ránézésre úgy tűnhet, mintha valamelyik csallóközi nagyközségben járna, tökéletes a szlovákiai mobilszolgáltató térereje. Néhány üzlet kirakatában magyar és szlovák feliratokat is olvashatunk. Az utcanevek magyarul vannak feltüntetve, a községi hivatal falán magyar és német nyelvü táblák. Az utcán szinte fele-fele arányban látunk magyar és szlovák rendszámú autókat" (Bartalos 2015).

2017-ben a lakosságszám elérte az 5300 főt, ebből körülbelül 3300 lakos rendelkezett bejelentett lakcímmel. A KSH viszont csupán 2843 lelket tartott nyilván, a különbség valószínüleg abból fakad, hogy a Központi Statisztikai Hivatal a népszámlálások közé eső években továbbvezetett népmozgalmi adatokkal számol. A fennmaradó 2000 fő kivétel nélkül szlovákiai származású, de a bejelentkezettek között is legalább 1000 fó tartozik ehhez a közösséghez. Együttes arányuk a község népességének csaknem 60\%-át teszi ki. Közülük legalább 1000 főnek magyar az anyanyelve, így - egyelőre - Rajka népességében a magyarok vannak többségben. Az évek során a szlovákiai magyarok súlya folyamatosan nőtt, az összes pozsonyi származású közül tíz éve 18\%, jelenleg 33\% tekinti magát magyar nemzetiségűnek (Lampl 2010). Az őslakos rajkaiak elköltözése folyamatos, de 2012 óta mérséklődött, ma a korábbinál nagyobb hang- 
súlyt kap a megüresedő házak (amelynek meghalt a lakója) felvásárlása az örökösöktől. Emellett új ingatlan építése, új lakás vásárlása, régi épületek felújítása is jellemző: mintegy 500 ingatlant vásároltak meg a szlovákiaiak (Hvg.hu 2017). A jelenlegi rendezési terv szerint a község népessége körülbelül 7000 főig nőhet, ennél nagyobb lélekszámhoz új beépíthető területeket szükséges kijelölni. A jelenleg készülő családi házak, illetve lakóparkok benépesülését követően Rajka ezt a lakosságszámot várhatóan 5-6 éven belül eléri (Torontáli 2017).

A két közösség viszonyát elemezve a békés együttélés helyett inkább egymás mellett élésről beszélhetünk. Nyugtalanító gondolat, hogy a térbeli elzárkózás (külön lakónegyed, ahol még mindig a betelepülők nagyobbik fele él) és az egymás iránti érdeklődés alacsony szintje szakadékként ékelődik régiek és újak közé, ami a beköltözések folytatódásával, a tudatos integráció és a beilleszkedésre való törekvés hiányával a továbbiakban is fenn fog állni, illetve újratermeli önmagát. Lampl (2010, 102-103.) megfogalmazásában a térbeli közelségnek „közösségteremtő vetülete is van (...), viszont akár szegregáltan, akár elvegyülve élnek (...) más az értékrendjük, az életmódjuk, az életstílusuk, a szokásviláguk, minden bizonnyal az anyagi helyzetük is (...) Talán mindezek miatt sem akarnak/tudnak részt venni a település közösségi életében.” A pozsonyi hátterü rajkaiak egyelőre távol tartják magukat a falut érintő fontosabb ügyektől és az önkormányzati választásoktól (adatközlőink szerint mindössze egy betelepülő lakos jelöltette magát képviselőnek, de nem választották meg), viszont néhány éven belül már lehet, hogy jóval határozottabban akarják érvényesíteni az akaratukat (Torontáli 2017). Nem mindegy, hogy két egymásról tudomást alig vevő csoport fog élni akkor Rajkán, vagy egy közösség.

\section{Heterogén faluközpont, homogén új negyedek}

„Van olyan érdekes helyzet, itt ebben a Béke utcában. A Béke utcát az 1950-es években épitették be az akkori fiatalok. Ezek most halnak ki sorba, és ahogy halnak ki, szlovákok veszik meg. És van olyan mondjuk, hogy öt ház egymás mellett szlovák."

Az etnikai términtázat vizsgálatához a belterületet nyelvi-származási összkép alapján háztartásonként kategorizáltuk, illetve a helyi járművek rendszámait (mint a nyelvi tájkép egy sajátos adalékát) írtuk össze. Előbbi keretében az adatközlőink által javasolt közterületet, a Móricz Zsigmond utcát, a rendszámok esetében viszont három különböző falurészt is vizsgáltunk.

A términtázatot meghatározó tényező a (lakóhely szerinti) származás, a nyelv szerinti differenciálás csak másodlagos. Ez egyrészt abból adódik, hogy Rajka társadalmi csoportjai közötti különbségek főként az életmódra vezethetők vissza, amit leginkább a származási hely magyaráz. Másrészt, az adatközlők az egyes közterületek vagy háztartások életközösségeiről minden esetben meg tudták állapítani a migrációs hátteret (tehát hogy beköltözők laknak-e ott), 
de az ott élők anyanyelvét nem mindig tudták azonosítani. A cél nem is Rajka „etnikai térképének” megrajzolása volt, sokkal inkább egy jellemző falurészlet sokféleségének származás szerinti bemutatása.

Az 51 azonosított háztartás közül 30 pozsonyi hátterü, ebből az adatközlöink mindössze kettőnél jelezték, hogy lakói magyarul (is) beszélnek. Ugyan nem tudták pontosan beazonosítani a háztartásokban élők nyelvi viszonyait, viszont megjegyezték, hogy az említettnél biztosan magasabb a magyar anyanyelvü családok száma. A további 21 ingatlanban rajkai „őlakosok” élnek. Figyelemre méltó, hogy akadt köztük olyan, aki a második világháború után a Csehszlovákiának jutatott „pozsonyi hídfo”” területéről menekült Magyarországra, illetve a legközelebbi Rajkára (1. ábra).

„A sorban elöttem várakozó bácsi felháborodva beszélt, hogy mennyi szlovák jön Rajkára. Az eszébe sem jutott, hogy a világháború után ő Dunacsúnból jött át, és hogy a két dolog végül is nem áll olyan messze egymástól."

A Móricz Zsigmond utca Rajka központi (régi) településrészén helyezkedik el, ám háztartásainak többsége már pozsonyi hátterű. Vagyis az új lakók Rajka régebbi részeit (is) benépesítik. A Pozsonyból érkezők Rajka régi településrészébe történő folyamatos beáramlását alátámasztja a rendszámok felmérése is. Erre az adatgyüjtésre három különböző útvonalon, az új falurészben (a község keleti oldalán), a község központi részén, és a község nyugati, az épületek kora

1. ábra: A migrációs és etnikai folyamatok lenyomata egy rajkai utcában The impact of migration and ethnic processes in a street of Rajka

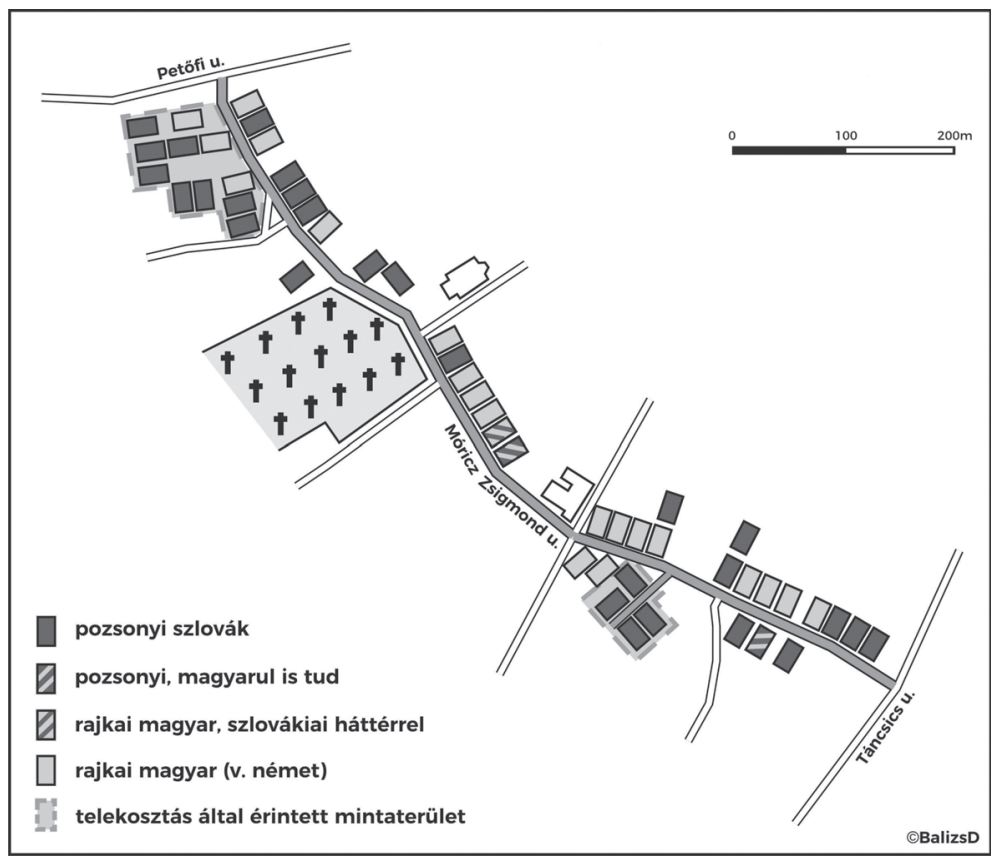


és jellege szerint vegyes zónájában (régebbi és új családi házak, illetve régi paneltömbök és új lakóparkok egyvelegében) került sor.

A felmérés kezdetén az új részeken (a lakóparkokkal együtt) a szlovák rendszámú autók elsöprő többségét feltételeztük, míg Rajka központi és egyéb régebbi utcáiban, nem elhanyagolható számú szlovák autó mellett a hazai járművek dominanciáját vártuk. A terepbejárás során törekedtünk arra, hogy minden jármű csak egyszer kerüljön be a mintába.

- Az újonnan beépülő negyedben a 196 autó 95\%-a volt szlovák rendszámú, ami megfelelt az előzetes várakozásoknak.

- A faluközpontban 147 jármü 51\%-án volt „SK” jelzés. A helyi általános iskolába szlovák diák alig jár, ennek megfelelően az intézmény előtt csak magyar rendszámú járművek parkoltak.

- A Rajka nyugati részét feltáró útvonalon 124 jármü csaknem felét (48\%-át) szintén Szlovákiában regisztrálták. ${ }^{4}$ A rajkai „lakóparkok” közül kettőt mértünk fel. Az első a falu északi peremén, a 150. számú út mellett helyezkedik el, hét tömbházából öt új, kettő régi építésű (panel). Az új épületek udvarán kizárólag szlovák, a régieknél jobbára hazai rendszámokat számláltunk össze. A falu déli részének három tömbháza (egy új, kettő panel) közelében érdekes módon csak szlovák autók parkoltak. A második és harmadik útvonalon tehát jóval magasabb volt a szlovák autók aránya, mint előzetesen vártuk (2.ábra).

2. ábra: Migrációs és etnikai folyamatok, illetve a terepbejárás útvonalai Rajkán Migration and ethnic processes in Rajka, and the route of fieldwork

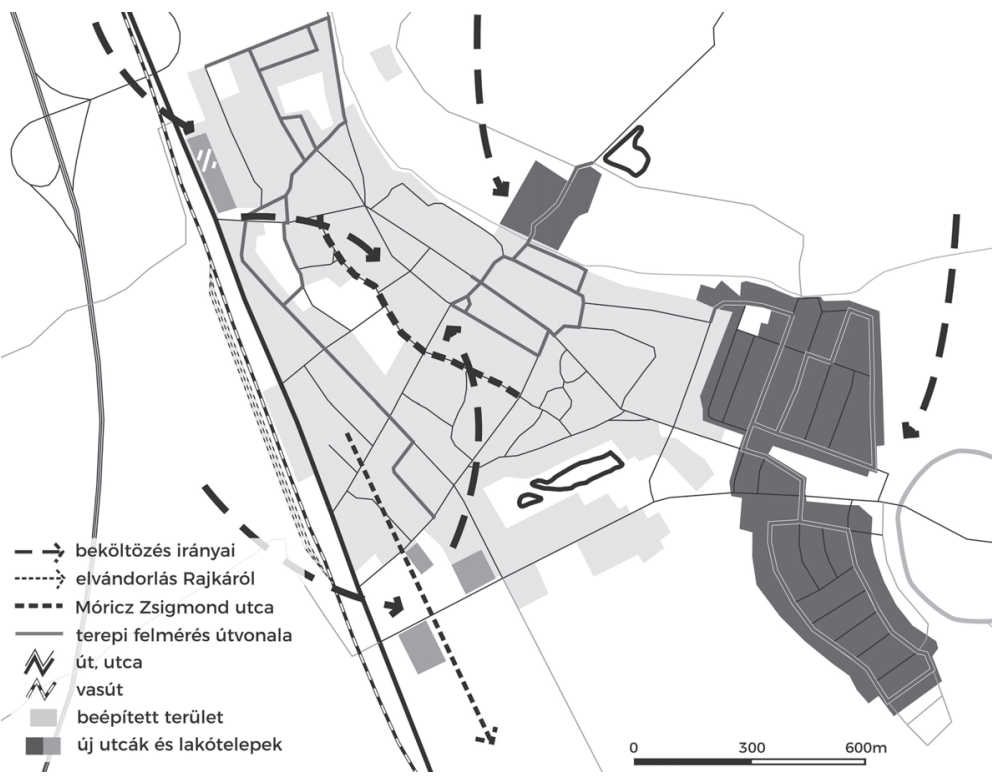




\section{Arculatvált(oz)ás}

Rajka településstruktúrájának és épületállományának átformálódását több tényező befolyásolja, a változások intenzív jellege, illetve az egyes folyamatok egyidejűsége viszont megkérdőjelezhetetlen. A lakások száma (2016-ban 1430) 1990 és 2016 között 70\%-kal nőtt, ennek csaknem 90\%-a a 2007 óta eltelt évekre esett. A növekedés üteme az utóbbi három évben - annak ellenére, hogy lassan telítődik a jelenleg beépíthetőnek nyilvánított terület, vagy talán éppen azért - tovább fokozódott (80-90 új lakás évente). A Google Street View adatbázisából letöltött képanyag és az általunk elvégzett terepmunka közötti öt és fél év Rajka egyes területein látványos változást mutat, ennek volumene számos esetben a helyszín azonosítását is nehezítette. Az új építésű településrészek közül a Dunakiliti felé tartó úttól északra 2011 végén az infrastruktúra kiépítése épphogy befejeződött (vagy még folyamatban volt), a frissen parcellázott telkek jelentős részén az épületek üresen álltak vagy félkész állapotban voltak. Jelenleg teljes a beépítettség, amely néhány ponton - telekosztás útján - további sürűsödést mutat. A Rajka-Dunakiliti út déli oldalán fekvő terület néhány éve még szántóföld volt. Mára itt is megvalósult a teljes beépítettség, sőt az egy főre jutó lakóterület a sorházas beépítés miatt alacsonyabb, mint az országúttól északra eső negyedben (3. ábra).

Teljes arculatváltásról mindemellett nem beszélhetünk, az építési szabályzatban foglaltakat az újonnan érkezőknek is kötelező betartaniuk (ami nagy

3. ábra: A Fakopáncs és a Pisztráng utca (2011. december és 2017. április)

Fakopáncs Street and Pisztráng Street (December 2011 and April 2017)
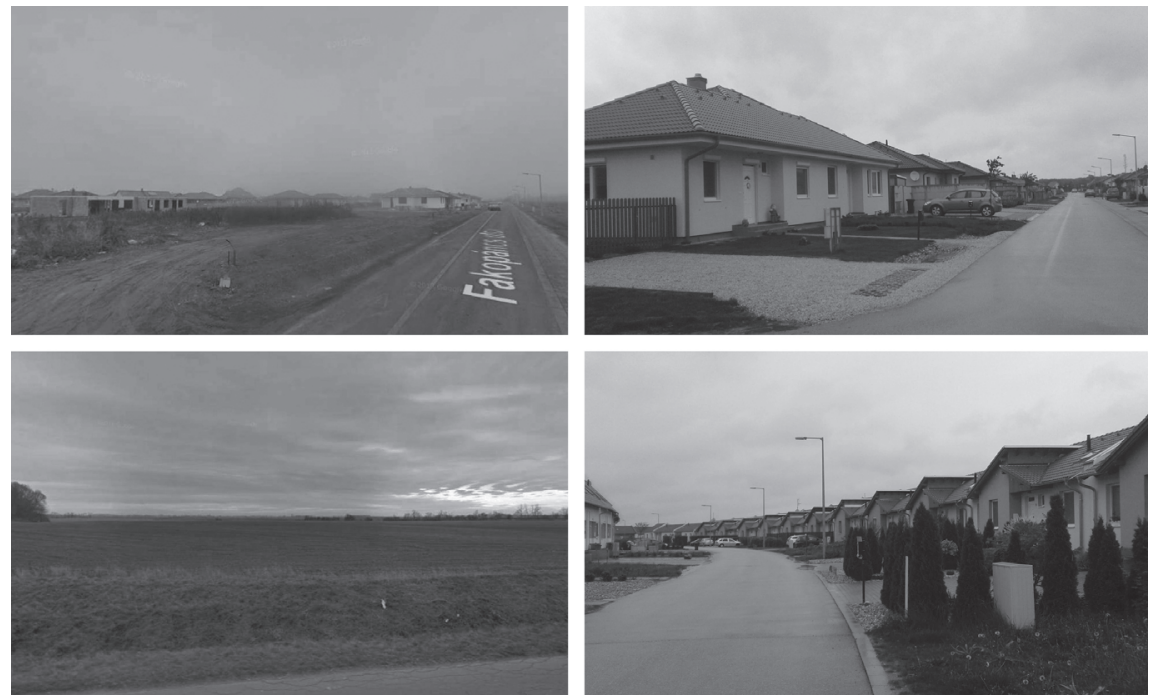

Forrás: Google Street View, illetve saját felvétel. 
népszerüsége ellenére sem engedi pl. a lapos tetőt). A belterületbe alig pár év alatt bevont, közművesített terület befogadóképessége már most megközelíti a 100\%-ot, alig két-három utcányi beépíthető rész maradt. Építési területté nyilvánításra alkalmas további hely a községtől északra található, ennek kijelölését azonban két tényező hátráltatja: a telkek közművesítése és a feltáró út építése másfél-két milliárd forintos beruházást igényel; a község vezetése és a lakosság pedig egyaránt vitatja Rajka beépített területének további bővítését, amely egyes vélemények szerint hosszú távon a vidéki jelleg elvesztéséhez, a falu élhetőségének romlásához vezet. Ezzel a település éppen azt a vonzerőt veszítené el, amely most a fejlődését meghatározza.

A helyhiány viszont nem jár együtt a kereslet mérséklődésével, emiatt az önkormányzat, dacára a terjeszkedéssel szembeni ellenérzésnek, a 2007 környéki időszakhoz hasonlóan ismét rákényszerül új építési terület kijelölésére. Az ingatlanárak sokéves emelkedést követően jelenleg stagnálnak, viszont ha elfogynak az üres telkek, újabb emelkedés várható. Ez nem lassítja a betelepülés ütemét, de továbbra is ingatlanjaik eladására, majd elköltözésre készteti az „őslakosokat”. Jellemző adalék, hogy 2008-ban az önkormányzat által kifejezetten rajkai családok számára kialakított és mélyen piaci ár alatt (3-4 ezer $\mathrm{Ft} / \mathrm{m}^{2}$ ) kínált ötven telekre 4 magyar és 304 szlovák jelentkező akadt (Élő 2008).

„Az a folyamat felgyorsult az utóbbi években, hogy már az összes létező szabad parcella, kezdik beépíteni. És az is ugye rohamosan fogy. Mert egy csomó, föleg, aki magyar anyanyelvü, Szlovákiából érkező magyar anyanyelvü, azok mind azt mondják, a régi Rajkán akarnak venni telket, nem ott kint. Mert ez a hangulatosabb."

Ugyanakkor az új utcákban jelentkező helyhiány nem csupán a régi településrész népszerűségének növekedését hozza magával. A telkek megosztása Rajkán egyre inkább terjed, mivel a viszonylag nagy méretű parcellák hátsó részén bőven elfér legalább még egy épület (családi ház). Ez részben visszavezethető generációs szokásokra: egy telken rajkai szokás szerint gyakran eredetileg is több ház állt, az időseknek és a fiataloknak külön-külön.

A migráció változatos jellegét mutatja a régi és az új településrészekbe történő beköltözés párhuzamossága, sőt előfordul a bevándorlás szakaszos típusa is (4. ábra). Utóbbi esetben a beköltöző először a község valamely új lakóparkjában (vagy régi paneltömbjében) jut lakáshoz, majd rövidesen továbbköltözik, jellemzően a falu régebbi (központi) részébe (5. ábra). Az új építésü utcákba költözők - szinte kivétel nélkül, az előbb leírt állomásokat kihagyva - közvetlenül új ingatlanokba települnek.

„Roppant érdekes és jellemzö, hogy akik társasházba jöttek, három-négy éve... ide, azok közt, még a szlovákiai szlovákok közt is, törekednek rá, hogy a régi Rajkán telket vegyenek és épitkezzenek. Vagy öreg házat megvesznek."

Ideillik azon fiatal kiköltöző család példája, mely négy-ötévnyi társasházi lét után új ingatlant épített a Fő utcán, a régit pedig eladta, valószínűleg egy másik kiköltözőnek. Anyagilag aligha járt jól, ám az ilyen esetek mutatják, hogy 
a hasonló gondolkodásúak akár jóval magasabb árat is hajlandóak megfizetni a „régi Rajkán” megszerzett vagy felépített ingatlanért, mint amennyit az új falurészben megengednének maguknak.

4. ábra: Utcakarakter-típusok Rajkán: rossz állapotban lévő régi épületek (balra fent); részben felújított kockaházak (jobbra fent); részben felújított, illetve teljesen átalakított kockaház új lakókkal (balra lent); felújított nyeregtetős házak új lakókkal (jobbra lent)

Types of street view in Rajka: old building in poor condition (upper left); partly renewed buildings (upper right), partly renewed and completely renewed building with newcomers (lower left), renewed buildings with newcomers (lower right)
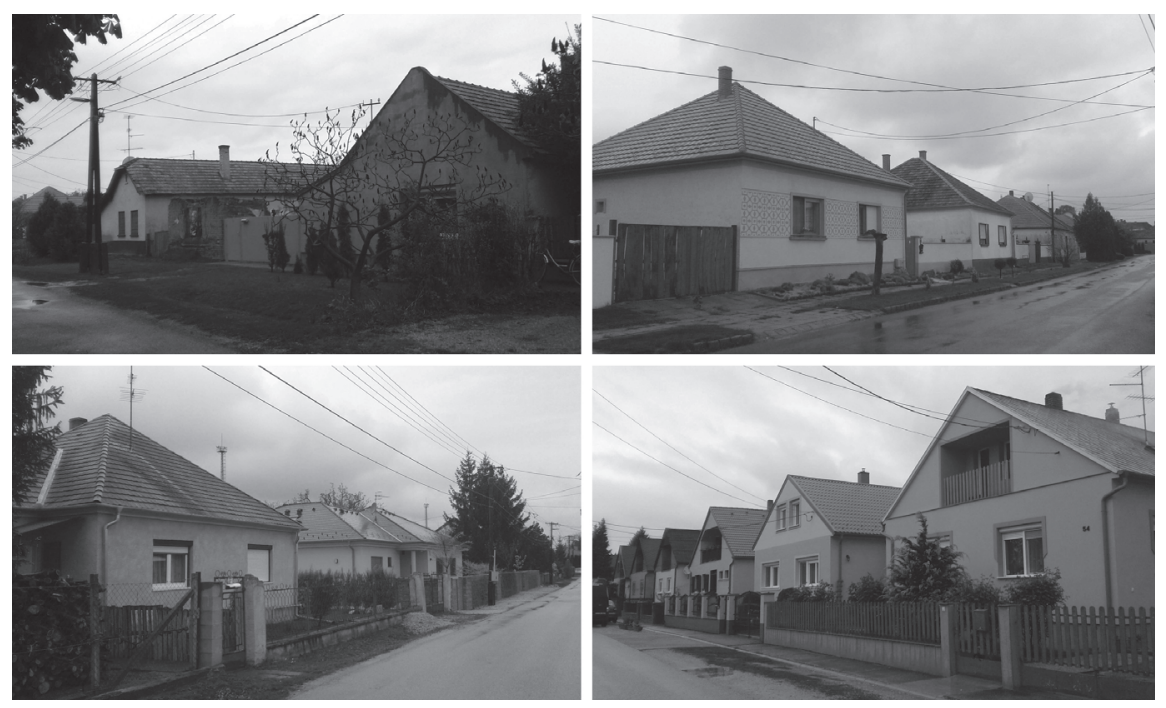

Forrás: saját felvétel.

5. ábra: Régi és új lakótelep

old and new housing estates
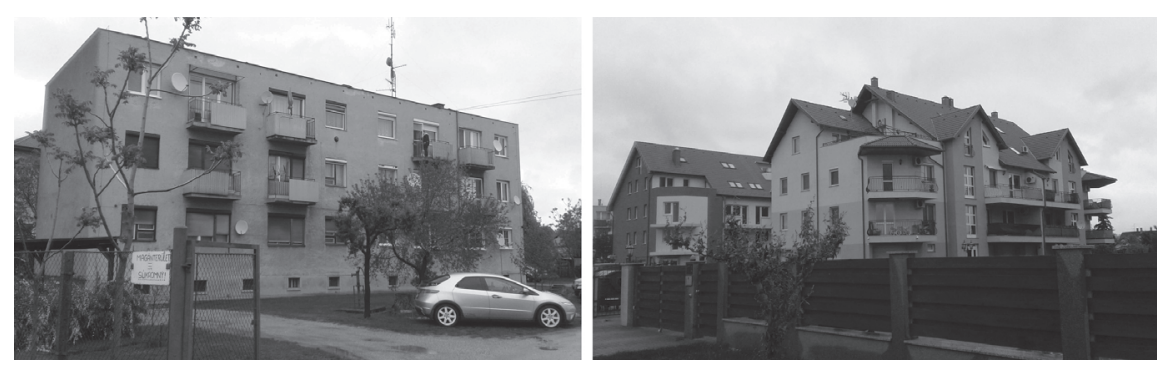

Forrás: saját felvétel. 


\section{Konklúzió}

A rajkai folyamatok sok tekintetben hasonlítanak más magyarországi településeken tapasztaltakhoz; ezek között említhetjük a szuburbanizáció határon átívelő jellegét (mint az átalakulás alapját), az őshonos és a beköltöző népesség között feszülő érdekellentéteket, az arculati változásokat, illetve a nyelvi viszonyok némileg ellentmondásos átformálódását. Utóbbin nagyszámú, nem magyarul beszélő lakos megjelenését értjük, akik az érintett települések nyelvi képének csupán bizonyos elemeit módosítják, mivel közösségi életbe történő bekapcsolódásuk, valamint a helyi intézmények és szolgáltatások használata (eddig) csak részben valósult meg. E jelenség nem csupán az etnikai mintázatot módosítja, hanem a gazdasági és szociális viszonyok lokális alakulása, illetve a település általános müködése miatt is nagyon fontos. A határon átnyúló szuburbanizációban érintett más településekhez hasonlóan az újonnan érkezők bizonyos hányada magyar anyanyelvü, ami a Kárpát-medencei magyarság területi elhelyezkedésére vezethető vissza. A sok hasonlóság mellett Rajka sajátosságát a folyamat kiemelten magas intenzitása adja, ami kétségkívül visszavezethető Pozsony mint főváros demográfiai és gazdasági erejére. Szintén egyedi vonás, hogy Rajka nyelvi jellege, alig 70 év alatt, immár másodszor esik át drasztikus változáson. Rajkának az is sajátossága, hogy a településen élő „őshonos” népesség elvándorlási rátája kiemelkedően magas, ami valószínűleg az eddig leírt folyamatokkal is magyarázható. Mindezekből adódóan Rajkára egyfajta példaként tekinthetünk, mint olyan településre, amely hazai viszonylatban „élen jár” a határon átívelő szuburbanizáció hatásait tekintve. Az itt zajló folyamatok tanulmányozása - egyediségük figyelembevétele mellett - más települések számára is hasznos tanulságokkal szolgálhat.

Az elmúlt évtizedben Rajka népessége, arculata számottevően átalakult, a Budapesttől 180 km-re elhelyezkedő község e néhány év alatt Pozsony magyar „külvárosává”, szuburbán településévé változott. Népességszáma több mint duplájára emelkedett, melynek már 60\%-a szlovák állampolgár. Az új lakók 500 ingatlant birtokolnak, kétharmaduk a Rajka keleti szélén felépült negyedekben talált otthonra, de sokan költöztek a falu régebbi utcáiba is, ahol az együttélés mozaikszerű mintázata alakult ki. Az új építési telkek elfogynak a közeljövőben, így a beköltözések súlypontja mindinkább a régi településrészre kerül, ahonnan az „őslakosok” elvándorolnak. Ez részben Rajka átalakulása, a vidéki miliő visszaszorulása miatt történik, másrészt nagy szerepet játszik e folyamatban az új lakóknak a régieknél sokkal kedvezőbb jövedelmi helyzete: a beköltözők számos esetben kivásárolják az őslakosokat ingatlanjaikból, akár a piaci árnál jóval magasabb összeget kínálva. Ennek révén a rajkai ingatlanárak is gyors emelkedésnek indultak, pár év alatt megduplázódtak.

A népesség növekedése, illetve kicserélődése folyamatos, és noha etnikainyelvi konfliktusok nem terhelik a két csoport viszonyát, a beilleszkedési nehézségek és a tudatos integráció csaknem teljes hiánya minimálisra szorítja le a 
„régi” és az „új” közösség közti interakció szintjét. A szlovákiai hátterü lakosokat munkahelyük, közösségi életük, oktatásuk továbbra is Pozsonyhoz kötik, alig veszik igénybe a rajkai szolgáltatásokat, jelentős részük bejelentés nélkül él a településen. Ez azt jelenti, hogy Rajka infrastruktúráját jóval több lakos használja, mint amennyien ennek fenntartásához hozzájárulnak. A megnövekedett népességszám és forgalom, a vidéki és az urbánus életmód közti eltérések feszültségeket okoznak az őslakosok és a bevándorlók körében. A mindennapi kommunikáció szintjén nincsenek konfliktusok, a jövőben a két közösség közti közeledés és párbeszéd elősegítése a cél.

A község arculata átalakult, a lakosság nyelvi-származási diverzitása jelentősen megnőtt. Napjainkban már a régebben épült utcákban is sok új lakóval, felújított vagy újonnan épült családi házzal, szlovák felirattal találkozhatunk. A régi településrész ma már a beköltözőknek is vonzóbb, mint az új lakónegyedek vagy a frissen felhúzott lakóparkokban épült lakások. Az épületek állapota gyakran a külső szemlélő előtt is nyilvánvalóvá teszi tulajdonosának származását. Az ingatlanok iránti kereslet továbbra is magas szintű, ami nemcsak a lakosok kicserélődését, hanem a beépítési sűrűség megnövekedését is maga után vonja (telekosztás). Nem könnyű a döntés azok számára, akik meg szeretnék őrizni Rajka falusias hangulatát: az építési terület bővítése nélkül a helyiek elköltöznek és helyükbe pozsonyiak érkeznek, míg új telkek kijelölésével a népesség további növekedése várható. Bármelyik forgatókönyv valósul meg, Rajka átalakulása folytatódni fog.

\section{Jegyzetek}

1 Rajkai lakos véleménye, 2012-ből (Alfahír 2012).

2 A szlovákiai oldalon nemcsak az ingatlanirodák reagáltak gyorsan az új helyzetre, hanem a politika is: az egyik párt (Egyszerü Emberek és Független Személyiségek - OLNO) a kampányát is kiterjesztette Rajkára (Győr+ Online 2012).

3 A népszámlálási nemzetiségi adatokat 2011-ben a „nemzetiség, anyanyelv, a családi, baráti közösségben használt nyelv válaszok legalább egyike szerint" publikálták. Így joggal feltételezhetjük, hogy az áttelepülő szlovákiai magyarok döntő része is szlovákként lett regisztrálva, mivel a mindennapi élet a szlovák nyelv használatát nélkülözhetetlenné teszi. Emiatt a népszámlálások adatsorai és a helyiek becslései (melyek minden átköltözőre vonatkoznak, akár szlovákok, akár szlovákiai magyarok) között módszertani ellentét nem mutatkozik, a 2011-es hivatalos és a 2017-es becsült értékek összevethetők egymással.

4 Egészen bizonyos, hogy a kedvezőbb díjak hatására a szlovákiai hátterüek mellett a rajkai „őslakosok” bizonyos (viszonylag alacsony) hányada is Szlovákiában regisztráltatta gépjárművét. Adatközlőink szerint viszont - mivel nem pontos értékek, csupán trendek felvázolását célozzuk - eredményeinket e tény érdemben nem befolyásolja. 


\section{Köszönetnyilvánítás}

Jelen kutatást a DANUrB projekt támogatta. A projekt a Duna Transznacionális Programból, az Európai Regionális Fejlesztési Alap támogatásával, az Európai Unió és a Magyar Állam társfinanszírozásával valósul meg.

\section{Irodalom}

Alfahír (2012): Átrajzolják a határt a szlovákok? Alfahír, október 12. http://alfahir.hu/atrajzoljak_a_ hatart_a_szlovakok-20121012 (Letöltés: 2017. november 9.)

Bajmócy P. (2007): Suburbanization in Hungary - expect the agglomeration of Budapest. In: Kovács Cs. (szerk.): Falvaktól a kibertérig. SZTE Gazdaság- és Társadalomföldrajz Tanszék, Szeged 139-149.

Balizs D. (2014): Felsőőr átalakuló etnikai és vallási térszerkezete. Földrajzi Közlemények, 4., 306-321.

Bartalos É. (2015): Rajka: összetartóbb a szlovák negyed. Új Szó, december 1. http://ujszo.com/ online/regio/2015/12/01/rajka-osszetartobb-a-szlovak-negyed (Letöltés: 2017. november 9.)

Berg, L. van den et al. (1982): A study of growth and decline. Pergamon Press, New York

Borsodi A. (2008): Feszültség a végeken. Magyar Nemzet, január 13. http://mno.hu/migr_1834/ feszultseg_a_vegeken-364085 (Letöltés: 2017. november 9.)

Cséfalvay A. (2008): A szlovákok inkább maradnának Rajkán. Kislföld, november 18. http://www. kisalfold.hu/mosonmagyarovari_hirek/a_szlovakok_inkabb_maradnanak_rajkan/2077771/ (Letöltés: 2017. november 9.)

Cséfalvay A. (2010): Ingatlanvita: inzultus a bezenyei hivatalban. Kisalföld, augusztus 28. http://www.kisalfold.hu/mosonmagyarovari_hirek/ingatlanvita_inzultus_a_bezenyei_ hivatalban/2175657/ (Letöltés: 2017. november 9.)

Cseke H. (2013): Szlovák ingatlanvásárlási roham a határszélén. Figyelo, október 6. http://archive. figyelo.hu/cikk_print.php?cid=szlovak-ingatlanvasarlasi-roham-a-hatarszelen (Letöltés: 2017. november 9.)

Dövényi Z., Kovács Z. (1999): A szuburbanizáció térbeni-társadalmi jellemzői Budapest környékén. Földrajzi Értesitö, 1-2., 33-57.

Du, Y., Shi, W., Liu, C. (2012): Research on an efficient method of license plate location. Physics Procedia, 24., 1990-1995. http://doi.org/cr42

Élő A. (2008): „Szlovákok leszünk teljesen!” - Magyarországon terjeszkedik Pozsony. bumm.sk április 11. http://www.bumm.sk/archivum/2008/04/11/17919_szlovakok-leszunk-teljesenmagyarorszagon-terjeszkedik-pozsony (Letöltés: 2017. november 9.)

Enyedi Gy. (1988): A városfejlődés szakaszai. Akadémiai Kiadó, Budapest

Fishman, R. (1987): Bourgeois utopias: The rise and fall of suburbia. Basic Books, New York

Győr+ Online (2012): Az egyik szlovák párt képviselőjelöltjei Rajkán is kampányolnak. Győr+ Online, február 24. http://gyorplusz.hu/cikk/az_egyik_szlovak_part_kepviselojeloltjei_rajkan_is_ kampanyolnak.html (Letöltés: 2017. november 9.)

Hardi T. (2008): A határtérség térszerkezeti jellemzői. Tér és Társadalom, 3., 3-25. https://doi.org/10.17649/ TET.22.3.1183

Hardi T. (2010): A szuburbanizáció jelensége és hatásai - határon innen és túl. In: Hardi T., Lados M., Tóth K. (szerk.): Magyar-szlovák agglomeráció Pozsony környékén. MTA Regionális Kutatások Központja, Fórum Kisebbségkutató Intézet, Győr, Somorja, 11-26.

Hardi T. (2011): A határon átnyúló ingázás mint a nemzetközi migráció egy különleges formája: A határon átnyúló szuburbanizáció - Pozsony esete. In: Róbert P. (szerk.): Magyarország társadalmi-gazdasági helyzete a 21. század első évtizedeiben. Széchenyi István Egyetem, Győr http://kgk.sze.hu/images/dokumentumok/kautzkiadvany2011/ujkormanyzas/HardiT.pdf (Letöltés: 2017. november 9.). 
Hardi T., Lampl Zs. (2008): Határon átnyúló ingázás a szlovák-magyar határtérségben. Tér és Társadalom 3., 109-126. https://doi.org/10.17649/TET.22.3.1188

Herczeg M. (2012): Még Fico meglepetésembere is minálunk vett házat. Index, április 13. https:// index.hu/belfold/2012/04/13/atvasaroljak_magukat_a_szlovakok_a_hataron/ (Letöltés: 2017. november 9.)

https://ingatlan.com/ (Letöltés: 2017. november 9.)

https://www.ingatlannet.hu/ (Letöltés: 2017. november 9.)

https://www.nehnutelnosti.sk/aktualne-ceny/ (Letöltés: 2017. november 9.)

Hvg.hu (2012): Rajka lakosságának szinte fele már szlovák. Hvg.hu, február 25. http://hvg.hu/ itthon/20120225_Rajka_bekoltozo_szlovakok (Letöltés: 2017. november 9.)

Hvg.hu (2017): Így lett Rajka szinte már Pozsony elővárosa. Hvg.hu, július 27. http://hvg.hu/ gazdasag/20170727_Igy_lett_Rajka_szinte_mar_Pozsony_elovarosa (Letöltés: 2017. november 9.)

Jagodič, D. (2010): Határon átívelő lakóhelyi mobilitás az Európai Unió belső határai mentén. In: Hardi T., Lados M., Tóth K. (szerk.): Magyar-szlovák agglomeráció Pozsony környékén. MTA Regionális Kutatások Központja, Fórum Kisebbségkutató Intézet, Győr, Somorja, 27-42.

Jagodič, D. (2011): Mobilità residenziale transfrontaliera nel contesto dell'Unione europea: il caso del confine italo-sloveno. Razprave in gradivo: revija za narodnostna vprašanja, 65., 60-87.

Keményfi R. (2002): A gömöri etnikai térmozaik. Fórum Kisebbségkutató Intézet, Lilium Aurum Könyvkiadó, Komárom, Dunaszerdahely

Krupč́́ková, K. (2013): Rajka - A model for peaceful coexistence? The Slovak Spectator, október 28. https://spectator.sme.sk/c/20048672/rajka-a-model-for-peaceful-coexistence.html (Letöltés: 2017. november 9.)

KSH (2017): Magyarország Helységnévtára. http://www.ksh.hu/apps/hntr.telepules?p_lang=HU\&p_id=26587 (Letöltés: 2017. november 9.)

KSH (é. n.): Népszámlálás 2011. http://www.ksh.hu/nepszamlalas/ (Letöltés: 2017. november 9.)

Lampl Zs. (2010): Túl a város peremén. Esettanulmány a Pozsonyból kiköltözött felső-csallóközi és Rajka környéki lakosságról. In: Hardi T., Lados M., Tóth K. (szerk.): Magyar-szlovák agglomeráció Pozsony környékén. MTA Regionális Kutatások Központja, Fórum Kisebbségkutató Intézet, Győr, Somorja, 77-131.

László É., Mayer P., Pénzes I., Rátz T. (2011): Szociológiai jellegű módszerek a turisztikai kutatásban. In: Kóródi M. (szerk.): Turizmus kutatások módszertana. Pécsi Tudományegyetem, Kempelen Farkas Hallgató Információs Központ, Pécs

Lovas Kiss A. (2011): The impacts of the European Union accession to the situation and the economic, social structure of several settlements of the region of Bihar. Debreceni Egyetem Néprajzi Tanszék, Debrecen (Ethnographica et Folkloristica Carpathica; 16.)

Mészely R. (2010): A pozsonyiak kiköltözése tovább folytatódik. Kisalföld, február 20. http://www.kisalfold.hu/mosonmagyarovari_hirek/a_pozsonyiak_kikoltozese_tovabb_ folytatodik/2142618/ (Letöltés: 2017. november 9.)

Munk V. (2009): Jól jár, aki a házát a szlovákoknak tudja adni. Index, október 8. https:// index.hu/belfold/2009/10/08/jol_jar_akinek_van_mit_eladni/ (Letöltés: 2017. november 9.)

Nový Čas (2015): Prihraničnú obec Rajka obsadili Slováci: Ako ich tam prijali mad’arskí obyvatelia? Nový Čas, november 10. https://www.cas.sk/clanok/335893/prihranicnu-obec-rajka-obsadilislovaci-ako-ich-tam-prijali-madarski-obyvatelia/ (Letöltés: 2017. november 9.)

Prates, R. C., Cámara-Chávez, G., Schwartz, W. R., Menotti, D. (2014): An adaptive vehicle license plate detection at higher matching degree. In: Bayro-Corrochano, E., Hancock, E. (eds): Progress in pattern recognition, image analysis, computer vision, and applications. CIARP 2014. Springer, Cham, 454-461. http://doi.org/cr43

Strüver, A. (2005): Spheres of transnationalism within the European Union: On open doors, thresholds and drawbridges along the Dutch-German border. Journal of Ethnic and Migration Studies, 2., 323-344. http://doi.org/c27r95

Tarics P. (2008): Rajka lassan szlovák lesz. Demokrata, 21. http://www.demokrata.hu/cikk/rajkalassan-szlovak-lesz (Letöltés: 2017. november 9.)

Tátrai P. (2006): Adalékok a települések belső etnikai térszerkezetének kutatásához. Földrajzi Értesítö, 3-4., 273-286. 
Teraz.sk (2015): Podla starostu Rajky pôvodní a noví obyvatelia vychádzajú spolu normálne. Teraz.sk, november 9. http://www.teraz.sk/slovensko/madarsko-prihranicna-obec-rajka/165246clanok.html (Letöltés: 2017. november 9.)

Terlouw, K. (2008): The discrepancy in PAMINA between the European image of a cross-border region and cross-border behaviour. GeoJournal, 2., 103-116. http://doi.org/cggzwd

Timár J. (1999): Elméleti kérdések a szuburbanizációról. Földrajzi Értesitő, 1-2., 7-32.

Torontáli Z. (2017): Ilyen a békés magyar-szlovák együttélés: van is, meg nincs is. Hvg.hu, március 20. http://hvg.hu/gazdasag/20170320_Ilyen_a_bekes_magyarszlovak_egyutteles_van_is_meg_nincs_is (Letöltés: 2017. november 9.)

Van Houtum, H., Gielis, R. (2006): Elastic migration: the case of the Dutch short-distance transmigrants in Belgian and German borderlands. Tijdschrift voor Economische en Sociale Geografie, 2., 195-202. http://doi.org/d75hdz 